\title{
Performance and Pollution Control Analysis of Municipal Solid Waste Incinerator Type Fluidized Bed
}

\author{
Agung Sudrajad ${ }^{1 *}$, Iman Syaefulloh ${ }^{1}$ \\ ${ }^{I}$ Mechanical Engineering Department Universitas Sultan Ageng Tirtayasa Jendral Sudirman Street Km. 3, Cilegon, \\ Banten \\ *Corresponding author. Email: agung@untirta.ac.id
}

\begin{abstract}
Incinerator produces power and heat from waste, reduces waste disposal, and reduces air pollution. The objective of the research of incinerator and ESP is to minimize air pollution in campus. UNTIRTA as a university having vision as a Smart and Green Campus, develops a municipal incinerator type fluidized bed with capacity $25 \mathrm{~kg}$. Incinerator made by $1.2 \mathrm{~mm}$ steel plat, complete with burner and air blower to supply the air for combustion process. Solid waste was collected from area inside the campus such as paper, plastics, and organics waste. The results shows that the incinerator is in good performance and also effectively reduce the exhaust emissions for pollution control in the campus.
\end{abstract}

\section{Keywords: Municipal Solid Waste, Incinerator, Fluidized bed, Pollution Control}

\section{INTRODUCTION}

The construction of the University of Sultan Ageng Tirtayasa campus in Sindangsari, Banten, Indonesia has been completed. The 12-hectare integrated campus is equipped with modern facilities. The future plan for the green and sustainability campus is to create an integrated waste management system in the campus. An integrated waste management system other than landfill is an incinerator system. Referring to the vision of the university, the research of incinerator inside campus becomes important. The incinerator is equipped with a particulate smoke reduction system using electrostatic precipitator (ESP) technology. The technological development requires researchers to create various tools that can provide comfort and health for humans. Clean air in the campus and green environment is a mandatory in the era of modern academic society. The smoke containing particulates can be harmful to human health [1]. The particulate air infects to the human body through the respiratory, it can cause irritation to the nose, throat and lungs. The particulate air is also resided in the lungs for a long time and it makes a serious damage in long-term reaction [2]. The current development issues of ESP and unsolved problems in the field of smoke filters have recently been summarized by Sudrajad [1], Mizuno [3] and Porle [4]. Journal by Hackam [5], focuses on controlling of air pollution using electric current with ESP technology. Recently, the trend of the air purifier industry is to increase the efficiency of reducing particulate emissions by utilizing filter technology that uses electrical effects.

Incinerator is a machine of the waste processing technologies through direct combustion with sufficient air at high temperatures. The incinerator converts waste materials into combustion gases and ash (bottom ash and fly ash). The temperature in the combustion chamber of incinerator can reach 800 to $1100^{\circ} \mathrm{C}$ and produces flue gas with a high temperature. This experiment uses Fluidized Bed (FB) Incinerator. It is an incinerator that uses sand media such as silica sand for mixing between the air and the grains of sand.

The ESP technology, a high voltage is applied to the wires to form an electrical field between the collecting plates, and ionizes the gas around the wires to supply ions. While the gas that contains dust or mist flows between the collecting plates and the wires, the air particles in the gas are charged by the ions. The Coulomb force caused by the high electric field by the wires causes the charged particles to be collected on the collecting plates and the gas is cleaned. This is the principle of electrostatic precipitation (ESP), and a small and large industrial applied ESP. Electrostatic precipitators are highly efficient filtration devices that minimally impede the flow of gases through the device, and can easily remove fine particulate matter such as dust and smoke from the air 
stream. Nowadays these ESPs are gaining importance to obtain the environmental clearance for setting up of new industrial plants and green environment [6]. Figure 1 shows the basic concept of ESP, while the air containing dust and smoke is filtered by ESP system.

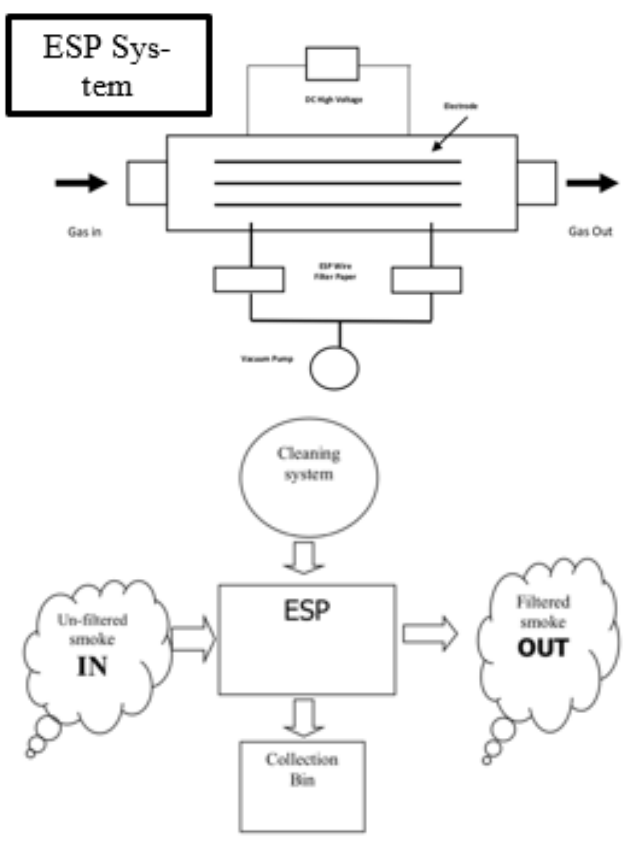

Figure 1. Schematic diagram of ESP [6]

\section{METHODS}

This research was conducted an incinerator capacity $25 \mathrm{~kg}$ at the Untirta Sindangsari campus and equipped with an ESP system. The waste used is plastic waste, leaves and paper obtained from campus waste. ESP is made using five plate units where each plate is equipped with a wire length $300 \mathrm{~mm}$ and diameter $0.1 \mathrm{~mm}$. The wires are connected to a DC high voltage supply and connected to the ground. The electrodes plate for collection made of stainless steel due to the aggressive gases and fumes, and also to avoid oxidation which will be caused by the use of water for washing. The voltage 5 until 35 $\mathrm{kV}$ (DC) from a DC power supply high-voltage is supplied to the plate and wire rod. The high voltage is required to produce a corona discharge which is caused by ionization of the aerosol particles surrounding a conductor. The corona power is a result from the current and voltage applied to produce an electric field. Particles through an electrode wire with a high negative charge will be negatively charged (carry negative change) and will be attracted to another electrode plat with a positive charge.

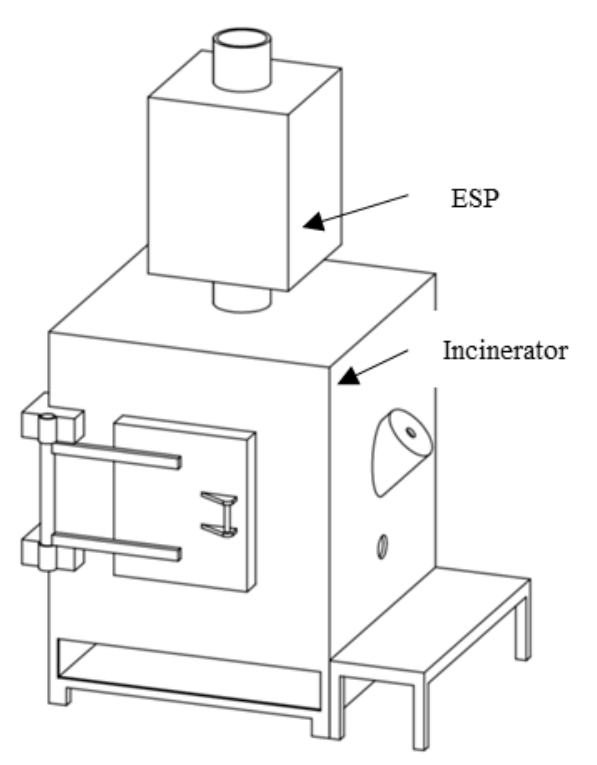

Figure 2. Schematic Diagram of Experimental

\section{RESULTS AND DISCUSSION}

The characteristics of particulate diameter as experimented by ESP were determined. Result of experimental data is shown in the filter paper without ESP and with ESP system for 5 until $35 \mathrm{KV}$ with range 5 $\mathrm{KV}$. The sample filter paper was tested using scanning Electron Microscope (SEM) at 5000 times magnification with SED detector. Figure 3 shows the SEM results with scale $2.5 \mathrm{~cm}: 10 \mu \mathrm{m}$.
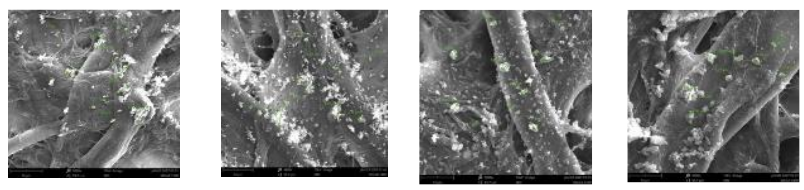

(a) Without ESP

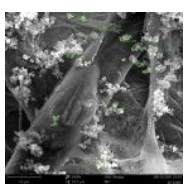

(b) ESP $5 \mathrm{KV}$

(c) ESP $10 \mathrm{KV}$
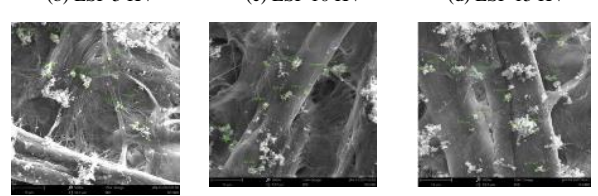

(e) ESP $20 \mathrm{KV}$

(f) ESP $25 \mathrm{KV}$

(g) ESP $30 \mathrm{KV}$

(h) ESP $35 \mathrm{KV}$

Figure 3. Results of SEM

The Figure above shows the SEM test results from filter paper samples taken from the exhaust gas of incinerator. Small particles that are micrometer in size represent the diameter of dust in the exhaust gas. The picture of the fiber seen in the photo by the SEM above shows the fiber on the filter paper. Calculation of the 
diameter particulates taken from clusters shaped like grapes. From the photos of SEM results, it can be seen that the higher voltage to the ESP plates the amount of particulate matter is less.

Table 1 Particulate Diameter by ESP Voltage

\begin{tabular}{|c|c|c|c|c|}
\hline & $\begin{array}{c}\text { Without } \\
\text { ESP }\end{array}$ & $\begin{array}{c}\text { ESP 5 } \\
\text { KV }\end{array}$ & $\begin{array}{c}\text { ESP 10 } \\
\text { KV }\end{array}$ & $\begin{array}{c}\text { ESP } \\
15 \\
\text { KV }\end{array}$ \\
\hline \multirow{2}{*}{$\begin{array}{c}\text { D aver- } \\
\text { age } \mu m\end{array}$} & $\begin{array}{c}2.64 \\
\text { ESP 20 } \\
\text { KV }\end{array}$ & $\begin{array}{c}\text { ESP 25 } \\
\text { KV }\end{array}$ & $\begin{array}{c}\text { ESP } \\
\text { 30KV }\end{array}$ & $\begin{array}{c}\text { ESP } \\
35 \mathrm{KV}\end{array}$ \\
\hline $\begin{array}{l}\text { D aver- } \\
\text { age } \mu m\end{array}$ & 3.33 & 3.64 & 3.81 & 4.17 \\
\hline
\end{tabular}

Table 1 shows the size of the particulate without ESP and using ESP at a voltage of 5 to $35 \mathrm{KV}$. From the table 1, it can be seen that the ESP voltage affects the size of the particulate diameter. The greater of voltage used in ESP, it will affect to the greater of size particulates that come out from ESP filter system. This is because dust with a small size will be captured by the plate on the ESP. A negative voltage wire will cause a corona effect in the area around the wire, by corona effect the small dust particles will be thrown towards the plate and patch.

\section{CONCLUSION}

The experimental for incinerators that equipped with electrostatic precipitators were presented. The effectiveness of corona discharge in ESP analyzed visually by using SEM. The filtration by using ESP process was found to be effective because a decrease in amount of particulate matter was observed from exhaust gas of incinerator. From the SEM results, it can be seen that the higher voltage to the ESP plates the amount of particulate matter is less and affect the greater size particulates that come out from ESP system. Because the device has no moving parts and is constructed from metal, it is quite robust. The activities of civitas academia on campus generate an increase in waste and risk of pollution. Therefore the using incinerator equipped with ESP is the best solution for the disposal of waste and reduce air pollution. The implementation of electrostatic precipitator for the incinerator in the university in this research was successful.

\section{ACKNOWLEDGMENT}

We would like to thank you very much for Research Grant of University of Sultan Ageng Tirtayasa for this research activity.

\section{REFERENCES}

[1] Sudrajad, Fitri, (2015). "A Review of Electrostatic Precipitator for Reduction of Diesel Emissions" Journal of Energy Procedia, May 2015

[2] I Setiawan, A. Sudrajad. (2020). Diameter Characteristics of Particulate Matter Indoor Air Pollution in Food Storage by Electrostatic Precipitator. International Journal of Advanced Science and Technology, 29(3), 2581-2585.

[3] Mizuno, A. (2000). "Electrostatic Precipitation." IEEE Transactions on Dielectrics and Electrical Insulation, 7(5), 615-624.

[4] Porle K., Kittelson, D. B., \& McMurry, P. H. (2004). "Structural properties of diesel exhaust particles measured by transmission electron microscopy (TEM): relationships to particle mass and mobility." Aerosol Science and Technology, 38, 881-889.

[5] Ibrahim Adabara et all. (2017). Design and Implementation of an Electrostatic Precipitator and Its Cleaning System for Small Scale Combustion. Indo-Iranian Journal of Scientific Research, Vol. 1Issue 1. Pages 213-224.

[6] Farid Miloua et all. (2013). Application of electrostatic precipitator in collection of smoke particles from hospital wastes combustion. International Journal of Environmental Studies. Vol. 70, No. 4, 527-535.

[7] Andersson, J. D., et al. (2004). "UK Particulate Measurement Programme (PMP): a Near US 2007 approach to heavy duty diesel particulate measurements - comparison with the Standard European Method." SAE Paper No. 2004-01-1990.

[8] Hackman, S., \& Maricq, M. (2002). "The role of fragmentation in defining the signature size distribution of diesel soot." Journal of Aerosol Science, 33, 935-942. 